\title{
Colonic adenocarcinoma resulting in recurrent colic and hematochezia in an Arabian stallion
}

\author{
Adenocarcinoomtumor van de dikke darm met recidiverende koliek en hematochezia \\ bij een Arabische hengst
}

${ }^{1}$ R. Maalouf, ${ }^{2}$ S. Alonso-Sousa, ${ }^{3}$ R. Graham

${ }^{1}$ Biyada, Street 11, Cornet Chehwan, Lebanon

${ }^{2}$ Central Equine Vets, 109 Swanston Road, Edinburgh EH10 7DS, United Kingdom

${ }^{3}$ Sharjah Equine Hospital, Bridge \#6,Al Dhaid Road, Al Atain, Sharjah, United Arab Emirates

ralphmlf@gmail.com

\begin{abstract}
$\Lambda_{\text {bstract }}$
A fourteen-year-old Arabian stallion was presented with general weakness and hematochezia. Clinical examination showed tachycardia but the rest of the physical parameters were within normal limits. Transcutaneous abdominal ultrasonography showed distended small intestinal loops with normal motility but increased mural thickness. Gastroscopic examination revealed small focal lesions in the non-glandular part of the stomach around the margo plicatus of the greater curvature, with a score of II/IV Equine Gastric Ulcer Syndrome. Blood analysis revealed anemia, hypoproteinemia and neutrophilia. Treatment was palliative and was determined based on the initial findings. Despite intensive medical treatment, the horse was euthanized due to progressive deterioration of its condition. Post-mortem necropsy and histopathology revealed an adenocarcinoma with osseous metaplasia within the left dorsal colon.
\end{abstract}

\section{SAMENVATTING}

Een veertienjarige Arabische hengst werd aangeboden vanwege algemene zwakte en hematochezia. Tijdens het klinisch onderzoek werd tachycardie vastgesteld. De overige fysieke parameters vertoonden normale waarden. Transcutane abdominale ultrasonografie wees op gedilateerde dunnedarmlussen met een normale motiliteit en een toegenomen wanddikte. Tijdens het gastroscopisch onderzoek werden kleine focale laesies aangetoond in het niet-glandulaire deel van de maag rond de margo plicatus van de curvatura major, met een score van II/IV voor maagzweren bij paarden. Tijdens het bloedonderzoek werden anemie, hypoproteïnemie en neutrofilie vastgesteld. De behandeling was palliatief en werd bepaald op basis van de eerste bevindingen. Ondanks de intensieve medische behandeling werd het paard vanwege een progressieve verslechtering van de toestand geëuthanaseerd. Tijdens de post-mortemnecropsie en het histopathologisch onderzoek werd een adenocarcinoom met osseuze metaplasie in de linkere dorsale dikke darm aangetoond.

\section{INTRODUCTION}

Equine intestinal adenocarcinoma (EIAC) has rarely been reported in horses (Jann et al., 2009), but represents the second-most common type of intestinal neoplasia in equids after lymphoma (Taylor et al., 2006), affecting middle-aged to older horses (East and Savage 1998). EIAC is more frequently localized in the cecum and ascending colon than in the small intestine (Head et al., 2002). EIAC can be associated with signs of recurrent colic, diarrhea, weight loss, anorexia, anemia and hyperfibrinogenemia (Wright and Edwards, 1984; Harvey-Micay, 1999). Ante-mortem diagnosis can be difficult and a definitive diagnosis is often made on post-mortem examination. The etiology of EIAC remains unknown, but in cattle and sheep, 


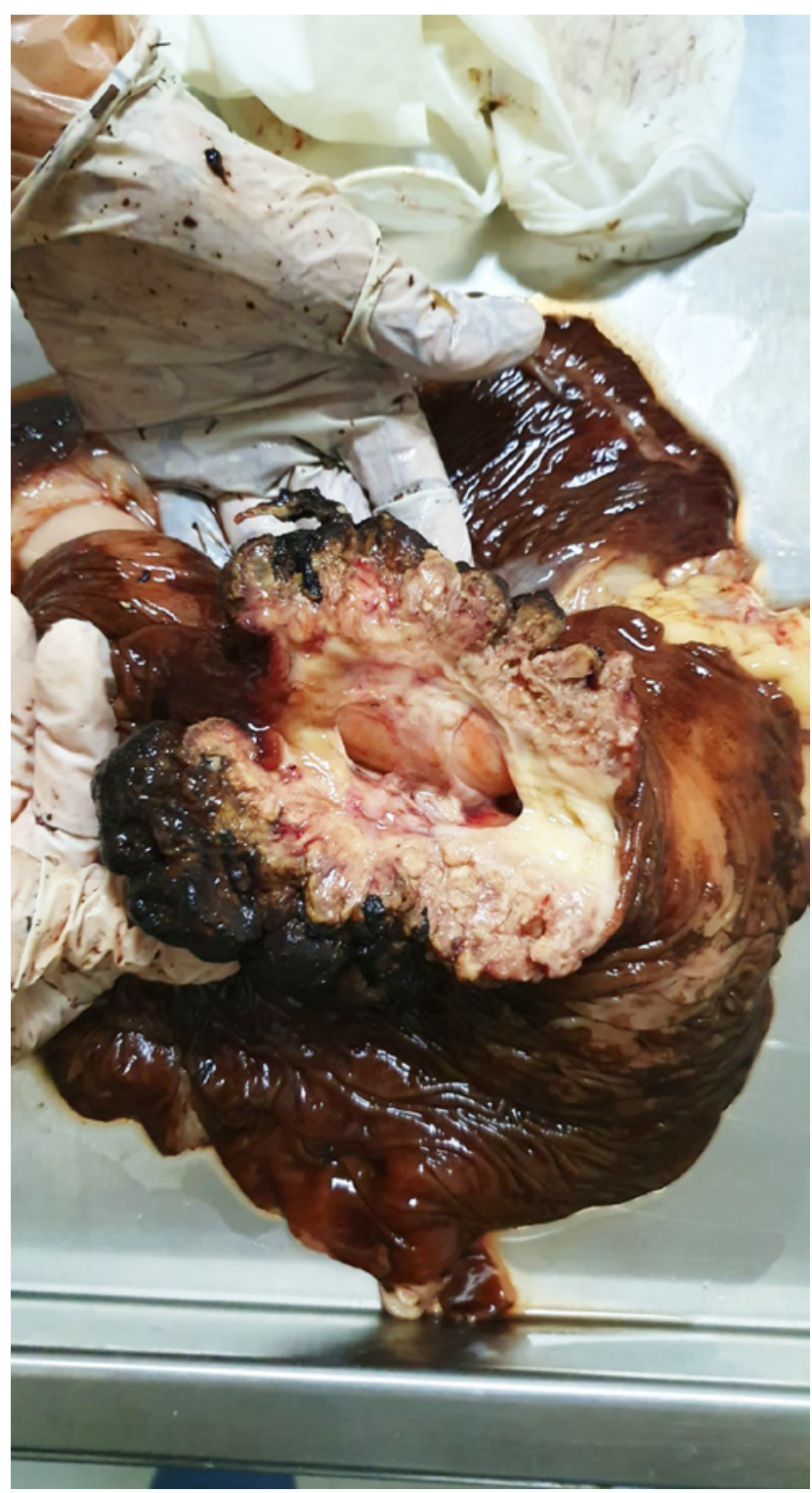

Figure 1. Cut surface of an intestinal adenocarcinoma of a fourteen-year-old Arabian stallion attached to the lumen of the left dorsal colon proximal to the pelvic flexure.

papillomavirus infection and exposure to bracken fern have been implicated as possible predisposing factors (Moran et al., 2008). In horses, inflammatory conditions such as inflammatory bowel disease have been suggested as etiologies of the disease (Nieminen and Farkkila, 2015). In this report, an adenocarcinoma with osseous metaplasia of the left dorsal colon associated with hematochezia in a fourteen-year-old Arabian stallion is described.

\section{History and clinical signs}

A fourteen- year-old Arabian stallion weighing $380 \mathrm{~kg}$ was presented at a referral hospital in the United Arab Emirates (UAE). The horse had been demonstrating progressive weight loss, recurrent signs of colic, inappetence and hematochezia. The horse had

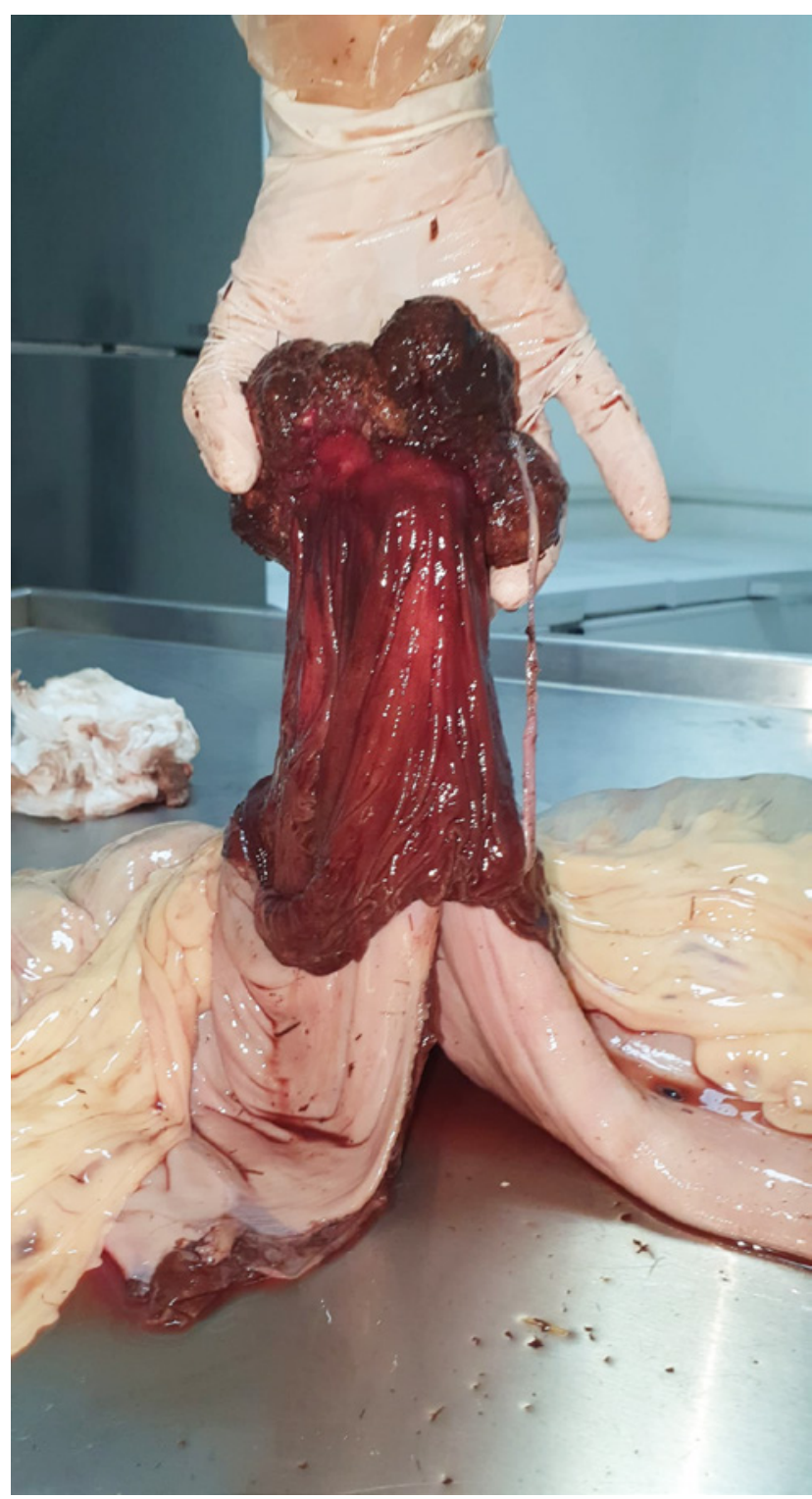

Figure 2. Intraluminal colonic adenocarcinoma in the left dorsal colon of a fourteen-year-old Arabian stallion.

a body condition score of 4/9 (Henneke et al., 1983) and had a history of regular and appropriate parasite control and dental care.

\section{Clinical findings and diagnosis}

On admission, the stallion presented with inappetence. Clinical examination demonstrated tachycardia (60 beats per minute), rectal temperature and respiratory rate were both within normal limits. Mucous membranes were pale-pink with a capillary refill time of two seconds. Gastrointestinal borborygmi were decreased in all quadrants. Rectal examination revealed melena with a slightly soft fecal consistency. Transcutaneous abdominal ultrasonography showed mildly distended small intestinal loops with normal motility and mild mural thickening $(12 \mathrm{~mm})$. The spleen was 
Table 1. Results of the blood analysis of the patient upon initial examination.

\begin{tabular}{lccc}
\hline Blood Values & Results & Units & Reference Range \\
\hline WBC & 10990 & cells $/ \mu \mathrm{L}$ & $4300-14800$ \\
RBC & 3580 & cells $\mu \mathrm{L}$ & $7200-12000$ \\
PCV & 16 & $\%$ & $31-50$ \\
Neutrophils & 9440 & $\mathrm{cells} / \mu \mathrm{L}$ & $28000-82800$ \\
Total Protein & 4.1 & $\mathrm{~g} / \mathrm{dL}$ & $5.6-7.9$ \\
$\mathrm{pH}$ & 7.219 & $\mathrm{mmol} / \mathrm{L}$ & $7.32-7.44$ \\
$\mathrm{HCO} 3$ & 17.9 & $\mathrm{mmol} / \mathrm{L}$ & $24-30$ \\
$\mathrm{~K}$ & 2.7 & & $2.8-4.6$ \\
\hline
\end{tabular}

visibly enlarged and extended to the $14^{\text {th }}$ intercostal space. There was increased echogenic content within the large colon with associated gaseous distension of the cecum. Gastroscopic examination revealed small focal ulcers in the squamous mucosa close to the margo plicatus of the greater curvature, scored as Equine Gastric Ulcer Syndrome grade II/IV (Andrew 1999). Blood analysis revealed metabolic acidosis and hypokalemia. The horse was anemic with decreased packed cell volume (PCV), decreased red blood cell (RBC) count; neutrophilia and hypoproteinemia were also present (Table 1).

Based on the blood results (with mainly the low PCV value) and the fact that piroplasmosis is endemic in the UAE, a blood sample was collected and polymerase chain reaction was positive for Babesia caballi and negative for Theileria equi. Fecal bacteriological examination was negative for Salmonella species.

\section{Treatment}

Treatment involved intravenous fluid therapy to correct electrolyte and metabolic disturbances, using Lactated Ringer's Solution (Ringer's Lactate; Wellpharma Medical Solutions, Abu Dhabi, UAE) at a rate of $3 \mathrm{ml} / \mathrm{kg} / \mathrm{hr}$, supplemented with sodium bicarbonate, $23 \%$ calcium borogluconate (C-B-Gluconat $24 \%$ plus $6 \%$; Bela-pharm, Vechta, Germany), and potassium chloride $(20 \mathrm{mEq} / 10 \mathrm{ml}$, Hospira, Inc., Lake Forest IL 60045 USA) for three consecutive days. In addition, two liters of thawed frozen plasma were administered intravenously. Flunixin meglumine (Banamine; MERCK Animal Health, Madison, New Jersey, USA) 1.1 $\mathrm{mg} / \mathrm{kg}$ bwt i.v. bid, dexamethasone (Colvasone, VMD Livestock Pharma, Arendonk, Belgium) $0.075 \mathrm{mg} / \mathrm{kg}$ bwt i.v. sid for three consecutive days, omeprazole (Gastrogard; Merial Inc., Duluth, Georgia, USA) 4 $\mathrm{mg} / \mathrm{kg}$ bwt p.o. sid, sucralfate (Sucralfate; Greenstone LLC, Peapack, new Jersey, USA) 20mg/kg bwt p.o. qid and probiotics p.o. sid (Pro Bio Equine; Mervue Laboratories, White Cross, Ireland) were included in the initial treatment protocol.

Iron supplementation (Troy Laboratories PTY. Limited, Glendenning, Australia), $13 \mathrm{ml} / \mathrm{kg}$ bwt administered once i.v., and $1 \mathrm{ml} / \mathrm{kg}$ bwt of tranexamic acid (Hemoplex,Pavesco AG, Basel) i.v. sid for three consecutive days were added later due to failure of improvement of the hematological values after 48 hours of treatment, despite progressive resolution of the acidosis and electrolyte imbalance.

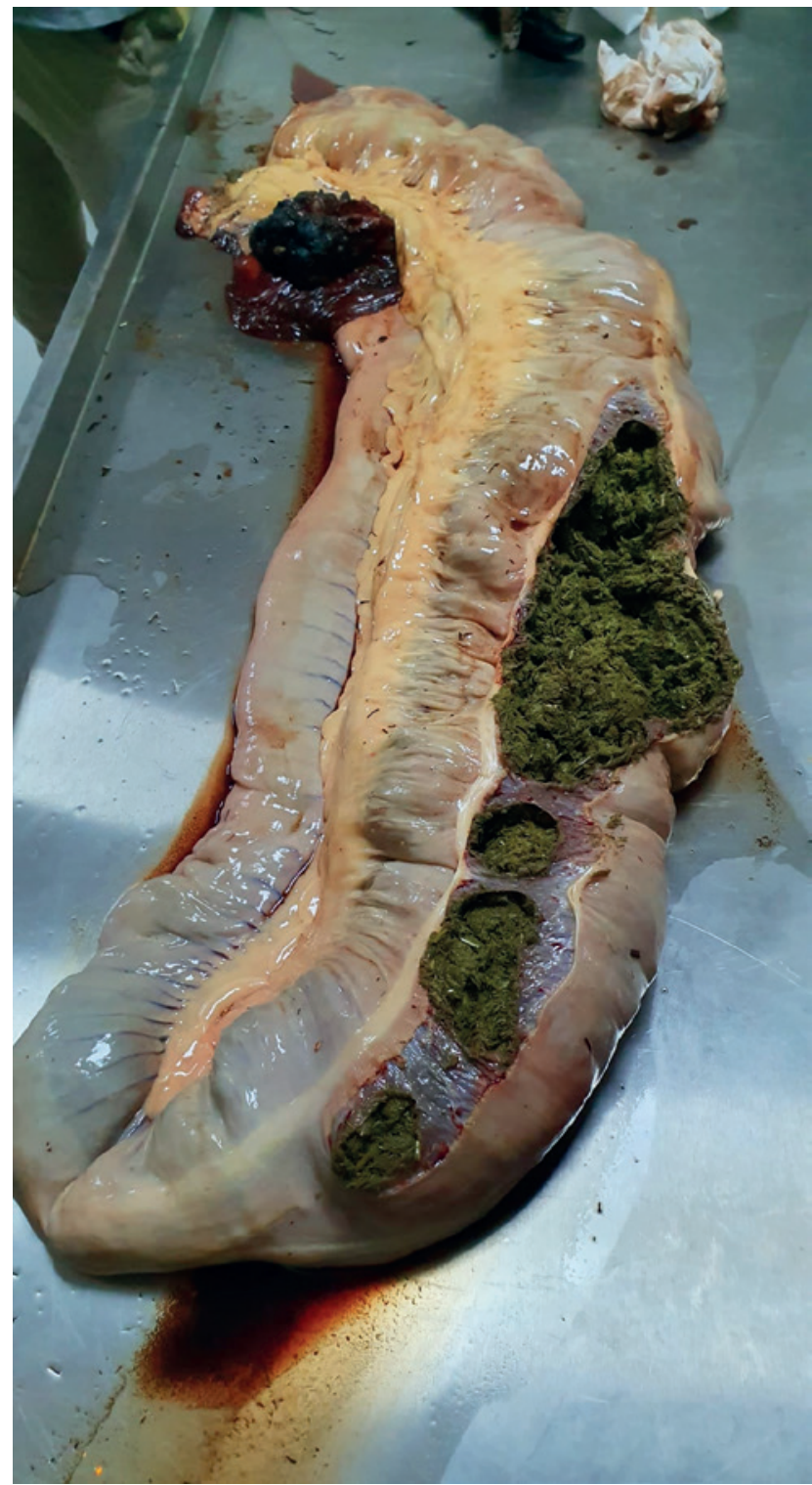

Figure 3. Post-mortem image of the colon showing the attachment of a mass to the left dorsal colon. 
Fluid therapy was reinstated as the horse's condition started to deteriorate five days after presentation, with tachycardia ( 60 beats per minute), pyrexia $\left(38.6^{\circ} \mathrm{C}\right)$, decreased PCV $(14 \%)$ and signs of abdominal discomfort being noted. Repeated hematological examination demonstrated further deterioration in the total RBC (2940 cells $/ \mu \mathrm{L})$ and total protein $(4 \mathrm{~g} /$ $\mathrm{dL})$. Repeated rectal examination demonstrated melena and a pelvic flexure impaction. Transcutaneous abdominal ultrasonographic examination showed similar findings to that of previous scans, with mildly distended and thickened small intestinal loops.

Based on clinical and laboratory findings, a course of corticosteroids was repeated. A tapering dose of $1 \mathrm{mg} / \mathrm{kg}$ bwt of Prednisolone (Prednisolone, VMD Livestock Pharma, Arendonk, Belgium) was administered i.m. bid for one week to be progressively decreased. The course of iron supplementation and tranexamic acid was repeated and a blood transfusion was carried out, which resulted in an improvement in hematological values.

A blood smear was performed to further investigate the cause of the continuous decline in PCV. The results showed a low quantity of erythrocytes with anisocytosis and metarubricytes, but no blood parasites were visible. A bone marrow aspiration collected from the sternum revealed decreased iron stores and an increased myeloid to erythroid ratio. However, the culture showed no bacterial growth.

Despite stabilization, the horse's condition began to deteriorate showing recurrent signs of abdominal discomfort with melena developing in the following days. Repeated hematological examination revealed anemia (4570 cells $/ \mu \mathrm{L})$ and hyperfibrinogenemia (777 mg/dL;RR200-450mg/dL). Reduction in the PCV $(20 \%)$ with worsened acidosis was also noted. Exploratory laparotomy was proposed to investigate the origin of the recurrent colic signs, but euthanasia was elected at this point.

On post-mortem examination, a large mass measuring $10 \times 5 \times 20 \mathrm{~cm}$, dark red in color and with a firm consistency to the touch was located occupying the left dorsal colon (LDC), immediately orad to the diaphragmatic flexure, with fibrous attachments to the mucosa of the LDC and partially occluding the lumen (Figures 1, 2 and 3). The wall of the colon orad to the mass appeared grossly normal, with normal fecal content. However, the affected part of the colon was filled with hemorrhagic diarrhea and mucosa necrosis.

Histologically, small foci of partially mineralized metaplastic bone tissue with active osteoid deposition at the margins, whilst other areas contained necrotic cell debris colonized by bacteria with a thick layer of neutrophils and leucocytic exudate, were present. Neoplastic cells were seen infiltrating into the edge of the smooth muscle (Figures 4, 5 and 6). Based on the histopathological findings, a diagnosis of intestinal adenocarcinoma with osseous metaplasia of the LDC was made.

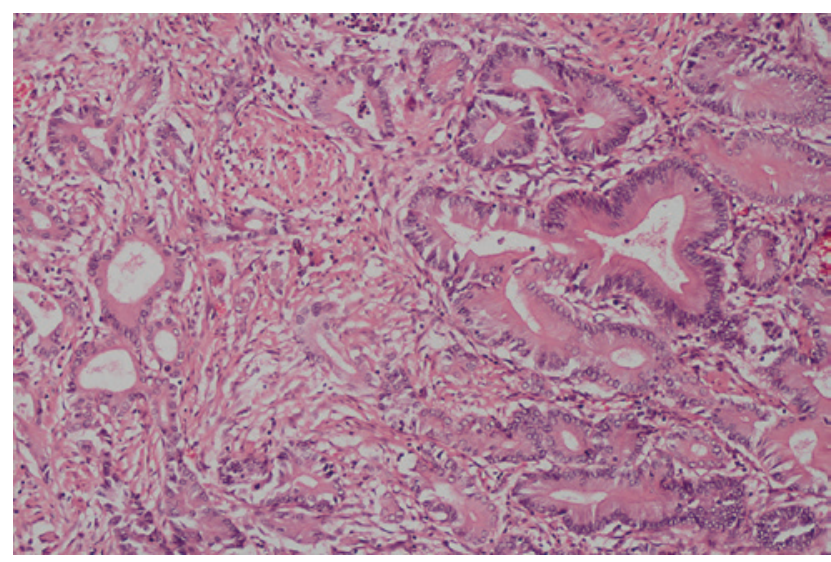

Figure 4. High-powered view (10x magnified, HE staining) of the adenocarcinoma. Details of the tubular structure, lined by a single layer of columnar cells with basal nuclei, sometimes infiltrated by inflammatory cells (mostly neutrophils), that may be detected also with the lumen of the tubuli. Sparse inflammatory cells are found also in the loose connective tissue of the stroma.

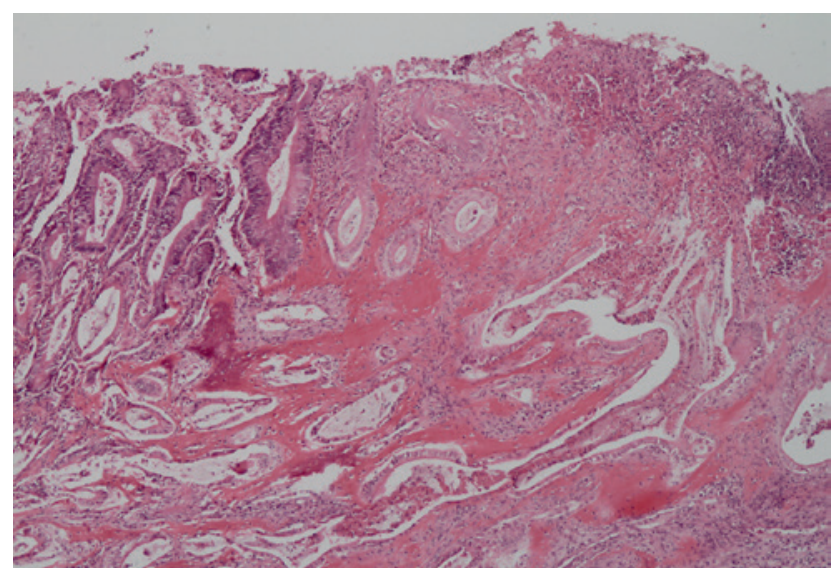

Figure 5. Section of the colonic mass $(25 x$, HE stainining). Tubular structures appear embedded in a variably coarse stroma, with coalescing areas of apparent mineralization/osseous metaplasia.

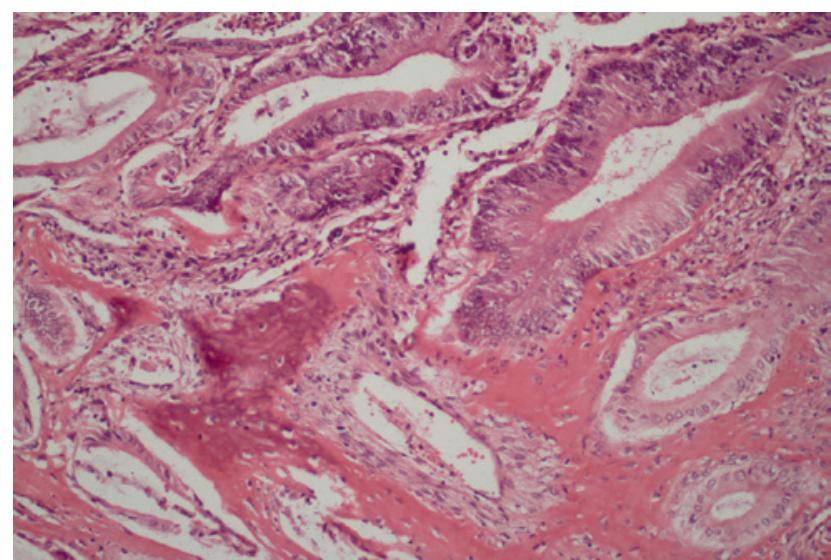

Figure 6. Section of the colonic mass (40x, HE staining). Details of the tubular structure, on which sometimes the typical columnar epithelium is replaced by cuboidal cells occasionally forming solid cords. In this image, connective tissue is replaced by an osteoid stroma, likely partially mineralized that surrounds the tubular structures. 


\section{DISCUSSION}

Intestinal carcinomas are generally rare in equids and other domestic animals. Intestinal adenocarcinoma is the second-most common type of intestinal carcinoma (Volker et al., 2017). As with other types of carcinoma, intestinal carcinomas are observed most commonly in older patients, with a mean patient age of twenty years (Taylor et al., 2006). In human medicine, transformation of a benign adenoma into a malignant adenocarcinoma can be caused by a mutation in the K-ras oncogene (Moran et al., 2008). Following malignant transformation, neoplastic cells metastasize to the skeleton and liver via the lymphatic system (Harvey-Micay, 1999).

Although there has yet to be a scientific explanation for the predisposition for intestinal tumors in canines and ruminants, Taylor et al. (2006) identified a trend in equids for a disproportionately higher number of adenocarcinomas diagnosed in Arabian horses compared to other breeds. Similarly, there is a breed predilection for this tumor in cats, with Siamese being more commonly afflicted than other breeds.

A definitive ante-mortem diagnosis of intestinal adenocarcinoma is difficult to establish as clinical symptoms tend to be vague and are often consistent with multiple other gastrointestinal conditions (Roy et al., 2002). The most common clinical signs include abdominal discomfort caused by partial or complete obstruction of the affected region of the gastrointestinal tract (Wright and Edwards, 1984). Fever, anorexia and weight loss as a result of the malabsorption caused by neoplastic infiltration of the intestinal and/ or colonic mucosa (Taylor et al., 2006), and melena or watery foul smelling diarrhea (Harvey-Micay, 1999) are also commonly seen in horses with intestinal carcinomas. Tachycardia and tachypnea are also regularly observed in these patients, with tachypnea being associated with possible multifocal lesions of the pleura (Taylor et al., 2006).

Hematological and biochemical analyses of venous blood tend to reveal progressive anemia, hypoalbuminemia, hyperglobulinemia and hyperfibrinogenemia, all of which are non-specific markers of chronic inflammation (Knottenbelt and Leverhulme, 2014). Anemia is a common pathological abnormality observed in these horses due to intestinal hemorrhage (Taylor et al., 2006) or secondary due to bone marrow suppression (Kirchhof et al., 1996).

Ultrasonography is an invaluable diagnostic method in the diagnosis of a wide variety if gastrointestinal diseases in horses. In the case of intestinal neoplasia, it may be possible to visualize and assess the mass in some cases (Reef, 2012). If abnormalities are detected during rectal examination, transrectal ultrasonography is indicated for the characterization of the findings. However in this case, no abnormalities were detected on rectal nor on transabdominal ultrasonographic examination.
Abdominocentes is another potentially useful diagnostic test to allow differentiation between colonic adenocarcinomas, inflammatory bowel disease, nonintestinal intra-abdominal neoplasia and internal abscessation (Fulton et al., 1990). In cases of intestinal neoplasia, exfoliation of the tumor may allow detection of neoplastic cells in the fluid (Knottenbelt and Leverhulme, 2014). However, this diagnostic technique is not always accurate as it fails to show neoplastic cells in cases of intraluminal and intramural tumors (Volker et al., 2017). Additionally, the presence of neoplastic cells confirms the presence of the tumor but is unable to pinpoint the exact location of the mass (Knottenbelt and Leverhulme, 2014).

A definitive ante-mortem diagnosis can be obtained by performing an exploratory laparotomy. Surgical resection of the affected region of the intestinal tract may be carried out concurrently and may be curative in some cases if performed early in the disease process. However, the non-specific nature of the condition often means that a definitive diagnosis is not made until the disease has reached an advanced stage, when extensive localized invasion and metastases have occurred and the prognosis for recovery is poor.

The clinical presentation and findings of the diagnostic tests in the present case were similar to those reported previously. However, the rapid deterioration of the patient and the poor outcome meant that exploratory laparotomy, an imperative diagnostic test to achieve a definitive diagnosis and establish a more accurate prognosis, was not pursued. Nonetheless, given the location of the tumor identified at post-mortem examination, euthanasia would likely have been elected even if celiotomy had been carried out.

This case report confirms findings from previous reports that EIAC develops more frequently in the large colon. Clinical signs are non-specific and diagnosis can be challenging. In most of the cases, the diagnosis is made post-mortem, and the tumors appear to be solitary with low metastatic potential but have the capacity to undergo osseous metaplasia. EIAC should be considered as a differential diagnosis in horses with recurrent colic and hematochezia of unknown origin.

\section{REFERENCES}

Andrews, F., Bernard, W., Byars, D., Cohen, N., Divers, T., MacAllister, C., McGladdery, A., Merritt, A., Muray, M., Orsini, J., Snyder, J., Vatistas, N. (1999). Recommendations for the diagnosis and treatment of equine gastric ulcer syndrome (EGUS). Equine Veterinary Education 11(5), 262-272.

East, L.M., Savage, C.J. (1998). Abdominal neoplasia (excluding urogenital tract). Veterinary Clinics of North America: Equine Practice 14(3), 475-493.

Fulton, I.C., Brown, C.M., Yamini, B. (1990). Adenocarcinoma of intestinal origin in a horse: diagnosis by abdominocentesis and laparoscopy. Equine Veterinary Journal 22 (6), 447-448. 
Harvey-Micay, J. (1999). Intestinal adenocarcinoma causing recurrent colic in the horse. Canadian Veterinary Journal 40, 729-730.

Head, K.W., Else, R.W., Dubielzig, R.R. (2002). Tumours of the alimentary tract. In: Meuten D. J. (editor). Tumours in Domestic Animals. Iowa State Press, Ames. pp 401-482.

Henneke, DR., Potter, GD., Kreider, JL., Yeates, BF., (1983). Relationship between condition score, physical measurements and body fat percentage in mares. Equine Veterinary Journal 15, 371-372.

Jann, H., Breshears, M., Allison, R., Pechman, R., Day, J., Hart, J., Moorman, V. (2009). Occult metastatic intestinal adenocarcinoma resulting in pathological fracture of the proximal humerus. Equine Veterinary Journal 41, 915917.

Kirchhof, N., Steinhauer, D., Fey, K. (1996). Equine adenocarcinoma of the large intestine with osseous metaplasia. Journal of Comparative Pathology 114, 451-456.

Knottenbelt, D., Leverhulme, P. (2014). Gastrointestinal neoplasia. XX SIVE International Congress.

Moran, J.A.M., Lemberger, K., Cadore, J.L., Lepage, O.M. (2008). Small intestinal adenocarcinoma in conjuction with multiple adenomas causing acute colic in a horse. Journal Veterinary Diagnostic Investigation 20, 121-124.

Nieminen, U. Farkkila, M. (2015). Malignancies in inflammatory bowel disease. Scandinavian Journal of Gastroenterology 50, 81-89.
Reef, V.B. (2012). Ultrasound of the nonacute abdomen: gastrointestinal tract. American Association of Equine Practioners, Proceedings 58, 19-27.

Roy, M.F., Parente, E.J., Donaldson, M.T., Habecker, P., Axon, J. (2002). Successful treatment of a colonic adenocarcinoma in a horse. Equine Veterinary Journal 34 (1), 102-104.

Taylor, S.D., Pusterla, N., Vaughan, B., Whitcomb, M.B., Wilson, W.D. (2006). Intestinal neoplasia in horses. Journal Veterinary Internal Medicine 20, 1429-1436.

Volker, I., Puschmann, T., Michutta, J., Ohnesorge, B., Wohlsein, P. (2017). Intestinal adenocarcinoma in ponies: Clinical and pathological findings. Equine Veterinary Education 30, 630-634.

Wright, J., Edwards, G. (1984). Adenocarcinoma of the intestine in a horse: an unusual occurrence. Equine Veterinary Journal 16, 136-137.

\section{cc) creative}

2021 by the authors. Licensee Vlaams Diergeneeskundig Tijdschrift, Ghent University, Belgium. This article is an open access article distributed under the terms and conditions of the Creative Commons Attribution (CC BY) license (http://creativecommons.org/licenses/by/4.0/).

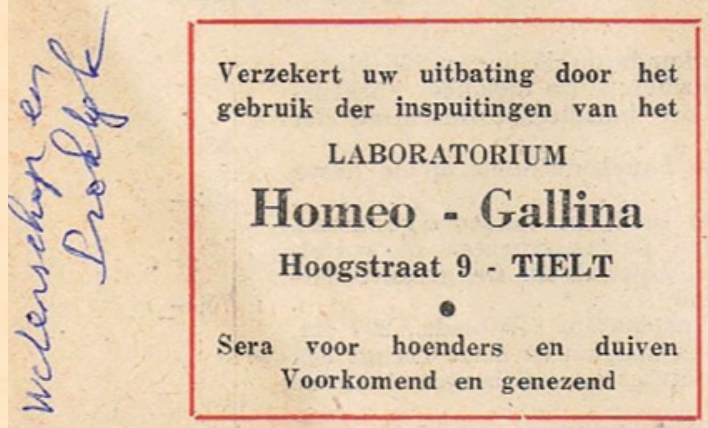

\section{Non Plus Ultra}

geneest en voorkomt met GROTE ZEKERHEID alle bacteriële besmettingen van luchtwegen en darmkanaal bij PLUIMVEE en DUIVEN.

Onfeilbaar ter genezing en voorkoming van COCCIDIOSIS en WORMEN.

Prijs per grote verpakking van 200 Pastillen: 65 Fr., franco per post tegen terugbetaling.

" HOLLANDS GLORIE », Heidebloemlei, 12 - SCHOTEN

Tel. 148.03

Drukkerij G. COOMANS \& A. DE STAERCKE, p. v. b. a., 123, Nieuwlandstraat, Brussel. 208 